\title{
Carcinosarcoma of head and neck; clinicopathological characteristics, treatment and outcomes of unique neoplasm
}

\author{
Abstract \\ Background: Carcinosarcoma of the Head and neck is rare neoplasm with incidence \\ of $<1 \%$. This is biphasic tumor with epithelial and mesenchymal components. Rarity \\ of this neoplasm is major obstacle to establish proper guidelines. Only few case series \\ and reports are available.
}

Aim: The aim of this study was to evaluate clinicopathological characteristics, treatment and its outcome to contribute in part to the better understanding and awareness of this rare malignancy.

Material and Methods: Retrospectively data of histological proven carcinosarcoma of head and neck from 2013 to 2015 was retrieved and evaluated for various parameters and also compared with both Indian and western data.

Results: Total of 5 patients of carcinosarcoma were registered within selected timeframe. The mean age of 44.8 years ranged from 27 years to 68 years. Male predominance was reported with M:F ratio 4:1.Oral cavity is most common site of tumor followed by oropharynx. Surgery is primary modality of treatment followed by adjuvant radiotherapy as per indication. Shortest follow up was 11 month and longest was 31 months. Only One patient was presented with recurrence.

Conclusion: The diagnosis of carcinosarcoma is challenging so histopathology along with immunohistochemistry is needed for appropriate diagnosis. Oral cavity seems to be the most common site with younger age group in present study which is supported by other Indian studies. Future studies are needed to define the geographical variation with clinicopathological character as well as treatment protocol for this relatively rare entity

Keywords: carcinosarcoma, head and neck, young age, treatment, outcomes
Volume 3 Issue 5 - 2017

\section{Garima Singh, Deepti sharma \\ Safdarjung hospital, India}

Correspondence: Garima Singh, Safdarjung hospital, H.No 307 Lady Hardinge Medical College Type 4, Staff Quarters, New Delhi, India, Tel 9953480093, Email singh.garima3025@gmail.com

Received: March 06, 2017| Published: July 20, 2017

\section{Introduction}

Carcinosarcoma is a rare (incidence of $<1 \%$ ) and unique variant of squamous cell carcinoma. ${ }^{1}$ These tumors are biphasic and it have been proved by many studies that it evolves from conventional squamous carcinoma with dedifferentiation associated with sarcomatoid transformation. ${ }^{2,3}$ Most commonly it arises from larynx, nasal cavity, hypopharynx, esophagus, trachea, oral mucosa. It has a male predominance with mean age of presentation in sixth decades of life with history of smoking, alcohol abuse, and radiation exposure. ${ }^{4,5}$ Immunohistochemistry along with routine histopathology is essential in establishing the diagnosis of spindle cell carcinoma. Here we are reporting five cases of spindle cell carcinoma in head and neck region to the better understanding and awareness of rare malignancy.

\section{Aim}

The aim of this study was to evaluate clinicopathological characteristics, treatment and its outcomes of patients of carcinosarcoma of head and neck to contribute in part to the better understanding and awareness of this rare malignancy.

\section{Material and methods}

The data of patients of carcinosarcoma of head and neck registered in Department of Radiotherapy, Safdarjung hospital, Delhi, India from Jan 2013 to Dec 2015 was retrieved retrospectively. The various parameters were evaluated and compared with both Indian and western data.

\section{Observation and results}

Total of 5 patients of carcinosarcoma were registered. Patients were in age group of 27 to 68 years with mean age of 44.8 years. Four patients were male and one was female. Three out of 5 patients had primary tumor site in oral cavity, one in oropharynx and one patient had primary lesion in larynx. $60 \%$ of cases were Stage III and $20 \%$ each of Stage II and Stage IV. Three patients had upfront surgery followed by adjuvant radiotherapy and two patients received radical radiotherapy as primary treatment. There was one recurrence after 1year of completion of treatment. One patient was lost to follow up. Three patients were on regular follow up and disease free. Follow up period ranged from 11 to 31 months (Table 1). 
Table I Patients clinicopathological characteristics, treatment and outcomes

\begin{tabular}{|c|c|c|c|c|c|c|c|c|c|}
\hline \multirow[b]{2}{*}{ No } & \multirow[b]{2}{*}{ Age } & \multirow[b]{2}{*}{ Habit } & \multirow[b]{2}{*}{ Gender } & \multirow{2}{*}{$\begin{array}{l}\text { Presenting } \\
\text { complaints }\end{array}$} & \multirow{2}{*}{$\begin{array}{l}\text { Primary } \\
\text { site }\end{array}$} & \multirow[b]{2}{*}{ Treatment } & \multicolumn{2}{|l|}{ Staging } & \multirow[b]{2}{*}{ Follow up } \\
\hline & & & & & & & $\begin{array}{l}\text { Clinical } \\
\text { staging }\end{array}$ & $\begin{array}{l}\text { Pathological } \\
\text { staging }\end{array}$ & \\
\hline I & 27 & $\begin{array}{l}\text { Tobacco } \\
\text { And } \\
\text { Bidi }\end{array}$ & Male & $\begin{array}{l}\text { Swelling left tonsil } \\
\text { and pain }\end{array}$ & Left Tonsil & $\begin{array}{l}\text { Left Tonsillectomy f/b RT } \\
\text { 66Gy/33\# }\end{array}$ & $\begin{array}{l}\text { cT2NIM0 } \\
\text { [Stage II] }\end{array}$ & $\begin{array}{l}\text { PT2NOM0 } \\
\text { [Stage II] }\end{array}$ & $\begin{array}{l}\text { On Regular } \\
\text { Follow Up } \\
3 \text { I months }\end{array}$ \\
\hline 2 & 27 & $\begin{array}{l}\text { Tobacco } \\
\text { And } \\
\text { Bidi }\end{array}$ & Male & $\begin{array}{l}\text { Ulceroproliferative } \\
\text { growth left buccal } \\
\text { mucosa }\end{array}$ & $\begin{array}{l}\text { Buccal } \\
\text { Mucosa } \\
+ \text { RMT }\end{array}$ & $\begin{array}{l}\text { Radical } \\
\text { radiotherapy with } \\
\text { chemotherapy } 70 \mathrm{~Gy} / 35 \#\end{array}$ & $\begin{array}{l}\text { cT3NOMO } \\
\text { [Stage III] }\end{array}$ & - & $\begin{array}{l}\text { Lost to follow } \\
\text { up After } \\
\text { treatment }\end{array}$ \\
\hline 3 & 40 & Bidi & Male & $\begin{array}{l}\text { Ulcer on right } \\
\text { lateral border of } \\
\text { tongue }\end{array}$ & $\begin{array}{l}\text { Right } \\
\text { Lateral } \\
\text { Border Of } \\
\text { Tongue }\end{array}$ & $\begin{array}{l}\text { Surgical Excision With } \\
\text { Neck Dissection }\end{array}$ & $\begin{array}{l}\text { cT3NIM0 } \\
\text { [Stage III] }\end{array}$ & $\begin{array}{l}\text { PT3NOM0 } \\
\text { [Stage III] }\end{array}$ & $\begin{array}{l}\text { On Regular } \\
\text { Follow Up } \\
\text { I I months }\end{array}$ \\
\hline 5 & 68 & $\begin{array}{l}\text { Tobacco } \\
\text { and Bidi }\end{array}$ & Female & $\begin{array}{l}\text { Swelling lower } \\
\text { alveolus }\end{array}$ & $\begin{array}{l}\text { Lower } \\
\text { Alveolus }\end{array}$ & $\begin{array}{l}\text { Surgery f/b Radiotherapy } \\
\text { with chemotherapy } \\
60 \mathrm{~Gy} / 30 \#\end{array}$ & $\begin{array}{l}\text { cT3NOM0 } \\
\text { [Stage III] }\end{array}$ & $\begin{array}{l}\text { PT3NOM0 } \\
\text { [Stage III] }\end{array}$ & $\begin{array}{l}\text { On Regular } \\
\text { Follow Up } \\
\text { I8months }\end{array}$ \\
\hline
\end{tabular}

\section{Discussion \& review of literature}

Carcinosarcoma are rare variant of squamous cell carcinoma. ${ }^{1}$ It consists of epithelial and mesenchymal components hence diagnosis is challenging and complex, Monoclonal hypothesis has been proved by many studies that both components have the same monoclonal origin with transformation and dedifferentiation of epithelial cell to spindle cells supported by immunohistochemistry. ${ }^{2,3}$ It usually occurs in males during $6^{\text {th }}$ and $7^{\text {th }}$ decades of life. Similar to other studies, ${ }^{4,5}$ male predominance was reported in this study with M:F ratio 4:1. Mean age was 44.8 years this is much below when we compared from western data of about 60 to 70 years. But Indian study by Viswanathan $\mathrm{S}$ et al., ${ }^{2,3}$ showed mean age of presentation was 53 and 58.18years respectively comparable to present study. Predisposing factors are smoking, alcohol consumption, previous radiation exposure. ${ }^{5}$ All 5 patients were chronic tobacco chewer and bidi smoker. Commonly it arises from larynx, nasal cavity, hypopharynx, oral cavity is rare site of presentation. ${ }^{1}$ In present study most common site of primary tumor was oral cavity contrary to western data. Here tobacco chewing is more common habit rather than smoking this might be the probable cause of increase incidence of oral cavity carcinosarcoma. ${ }^{5,6}$ None of the patients had prior history of exposure to radiation. $60 \%$ patients were of stage III and $20 \%$ each of stage II and stage IV. One patient $(20 \%)$ presented with nodal metastasis. The largest landmark study by Bataskis et al., ${ }^{3}$ showed nodal metastasis of $24 \%$. Carcinosarcoma is treated same as squamous cell carcinoma of head and neck there is no different established guidelines for this relatively rare entity.

\section{Conclusion}

Carcinosarcoma is a rare neoplasm with biphasic features, composed of both malignant epithelial and mesenchymal component In this study oral cavity is the most common site of presentation with younger age group. Though the data is very small so the statistical significance could not achieved but supported by other Indian studies where the similar finding was observed. So future studies are needed to define the geographical variation with clinicopathological character as well as treatment protocol for this relatively rare entity.

\section{Acknowledgements}

None.

\section{Conflict of interest}

Author declares that there is no conflict of interest.

\section{References}

1. Anderson CE, Al-Nafussi A. Spindle cell lesions of the head and neck: an overview and diagnostic approach. Diagnostic Histopathology. 2009; 15(5):264-272.

2. Gupta R, Singh S, Hedau S. Spindle cell carcinoma of head and neck: an immunohistochemical and molecular approach to its pathogenesis. $J$ Clin Pathol. 2007;60(5):472-475.

3. Chute DJ, Stelow EB. Cytology of head and neck squamous cell carcinoma variants. Diagn Cytopathol. 2010;38(1):65-80.

4. Viswanathan S, Rahman K, Pallavi S, et al. Sarcomatoid (spindle cell) carcinoma of the head and neck mucosal region: a clinicopathologic review of 103 cases from a tertiary referral cancer centre. Head Neck Pathol. 2010;4(4):265-275.

5. Tarun Kumar, Kiran Kothari, Mahesh H Patel, et al. Carcinosarcoma of Upper Aerodigestive Tract: A Case Series. Indian J Surg Oncol. 2011;2(4):316-319.

6. Stelow EB, Mills SE. Squamous cell carcinoma variants of the upper aerodigestive tract. American Journal of Clinical Pathology. 2005;124:S96-S109.

7. Batasakis JG. "Pseudosarcoma" of the mucous membrane in the head neck. J Laryngol Otol. 1981;95(3):311-316. 